\title{
DWIFUNGSI RUAS JALAN PENGALIH TEBANGAN LEMBAK SEBAGAI KOLAM KONTROL DEBIT
}

\author{
Fahmi Syaifudin dan Susilo Catur M.
}

Mine Planning Department, PT Kaltim Prima Coal

\begin{abstract}
ABSTRAK
Wilayah operasional Pit B/C PT Kaltim Prima Coal (KPC) area Bengalon terus melakukan ekspansi penambangan pada tahun 2019. Operasional pit akan memotong jalan umum dalam status Jalan Kabupaten penghubung desa Tebangan Lembak, Sepaso Barat dan kota kecamatan Bengalon. Salah satu ruas pemindahan jalan juga akan menjadi area tangkapan air limbah hasil operasional dumping Nakula Pit B/C yaitu pada titik penaatan kolam Kemuning. Penggunaan salah satu ruas jalan pengalih antara STA $2+100-2+375$ untuk sekaligus dijadikan kolam kontrol debit menjadi opsi yang menarik mengingat potensi penghematan akan didapat perusahaan. Riset ini menggunakan metode pendekatan kuantitatif dengan menghitung dan membandingkan volume pekerjaan tanah terhadap dua kondisi berbeda. Perhitungan penghematan didapatkan dengan memakai harga kontrak yang telah ditetapkan untuk pekerjaan konstruksi jalan. Biaya tambahan yang mencakup faktor non-teknis juga dimasukkan dalam perhitungan biaya karena penggunaan jalan ini perlu mendapatkan izin dari Bupati Kutai Timur. Dapat disimpulkan bahwa dengan integrasi pembangunan jalan pengalih sekaligus sebagai kolam kontrol debit air limbah tambang, KPC menghemat biaya konstruksi sebesar $41 \%$ dari total biaya konstruksi infrastruktur Pit B/C.
\end{abstract}

Kata kunci: Jalan pengalih, kontrol debit, titik penaatan.

\begin{abstract}
Operational area of Pit B/C PT Kaltim Prima Coal (KPC) continues to expand in 2019. Pit operation will cut public road with the status of connecting road between Tebangan Lembak village, West Sepaso and Bengalon sub-district. One of the re-alignment road segments will also be crossed by mining water flow from Nakula Dump activities at Pit B/C down to Kemuning Pond. Utilization those road segments between STA 2+100 to 2+375 to be control pond discharge shall be profitable for company. The research use quantitative approach by calculating and comparing earthwork volume for two different options. Saving calculation use the rate from approved contract for this road construction. Additional cost that covers non-technical issue also included in the calculation since utilization of road shall be approved by Bupati Kutai Timur. It is concluded that the integration of road and control pond discharge will save the cost for construction of Pit $B / C$ KPC infrastructure by $41 \%$.
\end{abstract}

Keywords: Road re-alignment, discharge control, compliance point.

\section{A. PENDAHULUAN}

Jalan Tebangan Lembak sepanjang 12,166km merupakan satu-satunya akses penghubung antara kota kecamatan Bengalon dan desa Tebangan Lembak. Berdasarkan peta jaringan jalan Bengalon, jalan Tebangan Lembak masuk pada peta ruas jalan kabupaten Kutai Timur dengan penanggung jawab jalan adalah Dinas Pekerjaan Kutai Timur. Kondisi saat ini, Dinas Pekerjaan Kutai Timur mengalokasikan program peningkatan mutu jalan menuju desa Tebangan Lembak dengan struktur 
perkerasan kaku (rigid pavement). Hingga tahun 2016, sepanjang kurang lebih 500m jalan dari STA 0+000 telah dilakukan pengecoran struktur jalan dengan beton mutu K-350 dan akan dilanjutkan pada tahun berikutnya hingga seluruh ruas jalan tercapai.

Pada tahun 2014, PT Kaltim Prima Coal (KPC) mengalokasikan program peningkatan infrastruktur di wilayah Bengalon melalui program Corporate Social Responsibility (CSR), salah satunya peningkatan kualitas jalan menuju desa Tebangan Lembak dengan pelapisan batu merah. Karena pertumbuhan penduduk dan pertumbuhan kegiatan ekonomi di desa Tebangan Lembak meningkat, maka aktifitas masyarakat yang melewati jalan ini juga meningkat. Peningkatan ini berdampak pada kerusakan jalan yang hanya memiliki perkerasan bersifat sementara (perkerasan batu merah) dan tanpa dilakukan perawatan rutin. Dasar inilah yang kemudian mendorong pemerintah kabupaten Kutai Timur sebagai penanggung jawab jalan untuk mengalokasikan program infrastruktur di daerah tersebut.

Pada tahun 2015, peningkatan jalan secara permanen mulai dilakukan Dinas Pekerjaan Kutai Timur dengan perkerasan kaku. Tahapan pertama yang dilakukan adalah melakukan perbaikan tanah dasar disepanjang jalan Tebangan Lembak dengan perkerasan batu merah setebal $15 \mathrm{~cm}$ dengan lebar $7 \mathrm{~m}$. Tahap ini selesai dikerjakan pada akhir 2015. Kemudian pada tahun 2016, Dinas Pekerjaan Umum hanya mampu mengerjakan pengecoran untuk perkerasan kaku sepanjang 500m dari STA 0+000. Saat permohonan ijin pengalihan jalan, spesifikasi akhir perkerasan yang diajukan KPC menyamakan dengan perkerasan akhir yang sudah dikerjakan oleh Dinas Pekerjaan Kutai Timur, yaitu berupa perkerasan batu merah. Secara teknis, permohonan ini disetujui.

Berdasarkan rencana jangka panjang 5 tahunan Dept. Mine Planning KPC, mulai akhir kuartal 4 tahun 2018 sebanyak total 41MT batu bara dari pit C yang berlokasi di utara jalan Tebangan Lembak akan ditambang dan material penutup overburden (OB) akan ditimbun tepat mengenai jalan eksisting Tebangan Lembak. Aktifitas tersebut akan memotong jalan Tebangan Lembak mulai dari STA 4+380 dan berakhir di STA 9+221 atau total sepanjang 4,841m ruas jalan yang terganggu aktifitas penambangan.

Berdasarkan peraturan Gubernur Provinsi Kalimantan Timur No. 10 tahun 2012 tentang penyelenggaraan jalan umum dan jalan khusus untuk pengangkutan Batubara dan Kelapa Sawit, setiap perusahaan diwajibkan membuat jalan khusus yang tidak berinteraksi langsung dengan lalu lintas umum. Sebagai pemenuhan peraturan pemerintah, KPC akan menggantikan jalan Tebangan Lembak yang terdampak aktifitas tambang dengan jalan baru di sisi Selatan jalan lama sepanjang $5,509 \mathrm{~km}$.

Dari total panjang $9,221 \mathrm{~km}$ jalan lama, sepanjang $4,841 \mathrm{~km}$ akan terpotong sebagai dampak dari pemanfaatan ruas jalan ini untuk operasional tambang. Sebagai penggantinya, KPC akan mengalihkan jalan tersebut dan membangun jalan pengganti di sisi Selatan jalan lama sepanjang $5,509 \mathrm{~km}$. Meskipun jalan pengalih lebih panjang 0,668km dari jalan lama, dengan perencanaan alinyemen vertikal dan horizontal yang mengikuti standar perencanaan jalan, dipastikan waktu tempuh jalan pengalih bisa lebih cepat dengan kenyamanan yang lebih tinggi.

Pit B/C Bengalon secara resmi telah masuk sebagai bagian rencana penambangan KPC pada tahun 2018. Penambangan perlu segera dimulai paling lambat pada kuartal 3 tahun 2018 hingga Life of Mine (LoM). DTA timbunan Nakula yang mengarah ke kolam kemuning (dimana kolam kontrol debitnya adalah jalan pengalih tebangan lembak) seluas $4,73 \mathrm{~km}^{2}$. Lebih dari separuhnya akan terganggu aktifitas penambangan sebagai area timbunan OB. Aliran air dari DTA mengalir langsung ke Sungai Bengalon melalui Sungai Bahau. Aliran air permukaan ketika hujan berpotensi menghasilkan sedimen akibat dari erosi pada area terganggu. Kolam penaatan diperlukan sebagai titik kontrol dan monitoring kualitas air sebelum aliran air dari area terganggu keluar menuju sungai atau badan air penerima. 


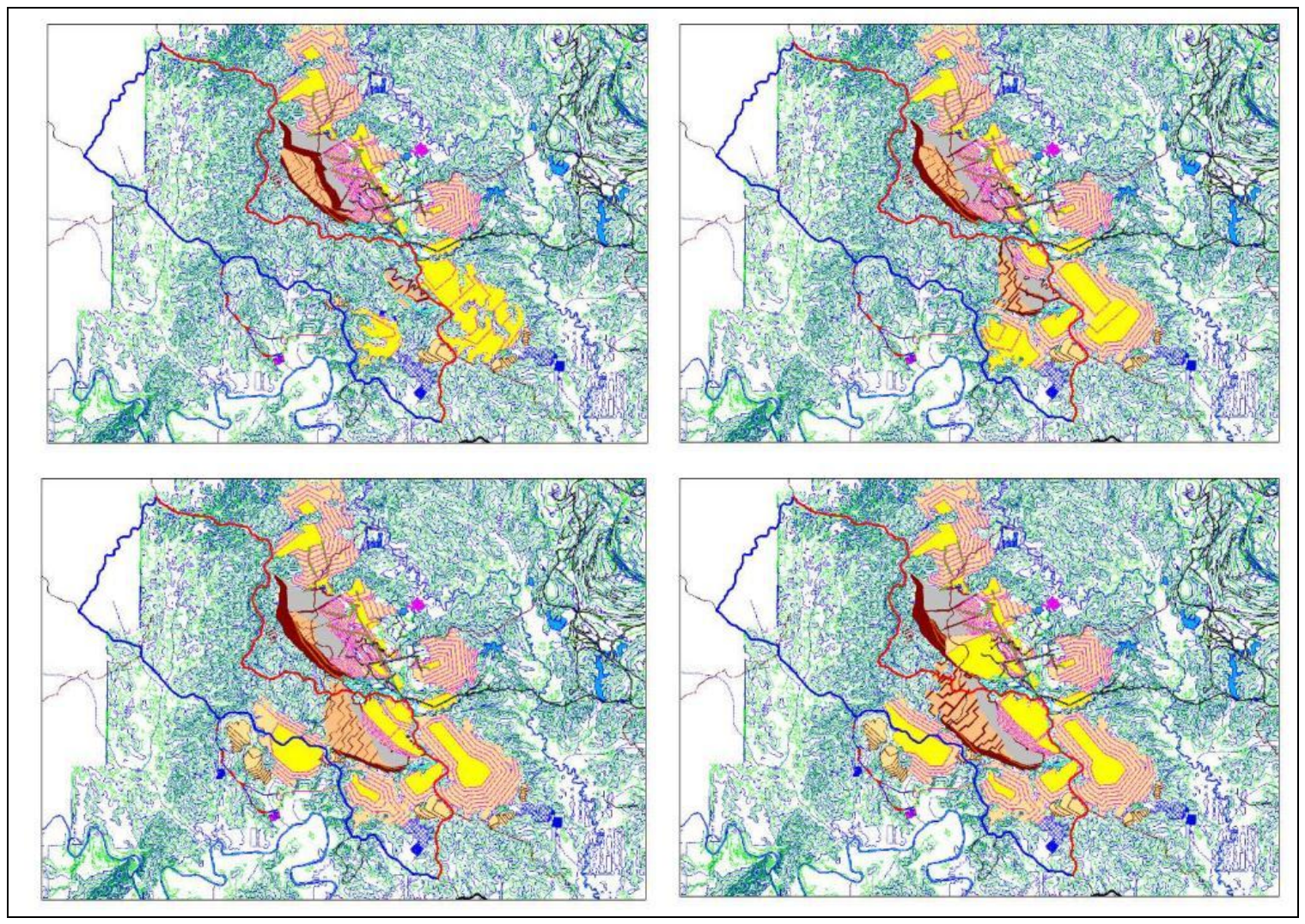

Gambar 1. Posisi muka tambang Pit B/C Bengalon 2018 - 2021

Atas kiri akhir tahun 2018, atas kanan akhir tahun 2019

Bawah kiri akhir tahun 2020, bawah kanan akhir tahun 2021

Ada 2 rangkaian kolam yang perlu dibangun oleh KPC dalam melakukan pengelolaan air limbah tambang. Kolam yang pertama yaitu kolam tipe blocking (sebagai kontrol debit) dan yang kedua adalah kolam labirin (sebagai kolam pengendapan). Kolam kontrol debit didesain secara spesifik untuk menunda debit banjir besar yang tercipta akibat hujan dimana umumnya juga membawa sampah dan sedimen tanah ketika hujan. Selain fungsi tersebut, kolam kontrol debit diharapakan juga dapat menyimpan butiran sedimen dalam ukuran besar yang terbawa hujan sehingga sedimen yang terbawa ke kolam labirin dapat diminimalkan.

\section{B. METODOLOGI PENELITIAN}

Penelitian dilakukan pada sisi perencanaan dimana ada beberapa input variabel yang dipertimbangkan dalam studi. Setidaknya ada 4 pertimbangan dalam penentuan alinyemen horizontal jalan pengalih Tebangan Lembak ini dalam fungsinya sekaligus sebagai kolam kontrol debit. Antara lain yaitu batas terluar kaki dumping desain timbunan OB Nakula pada Pit B/C, kondisi topografi, kondisi geografis, penempatan alinyemen jalan dengan tampungan hidup (live storage) yang paling optimum, dan status pembebasan lahan rencana alinyemen.

Pendekatan kuantitatif diambil dalam penyelesaian masalah, dimana terdapat 2 alternatif pilihan pemindahan jalan yang dapat dilakukan. 2 alternatif pilihan dihitung volume pekerjaan galian timbunan tanahnya dan dihitung masing-masing biaya yang timbul. Perhitungan volume galian dan timbunan dihitung dengan perangkat lunak Minex 6.3 dengan menggunakan data topografi KPC. Pembaruan data topografi terus dilakukan sejalan dengan progress pembersihan lahan di lapangan dimana terdapat perbedaan topografi antara topografi satelit dan topografi aktual. Data perhitungan yang disajikan menggunakan data topografi aktual. 
Data volume yang didapatkan berdasarkan pickup topografi aktual selanjutnya dikalikan dengan harga satuan pekerjaan. Harga satuan pekerjaan yang digunakan adalah data kontrak KPC No. 890069 untuk proyek "Konstruksi Pengalihan Jalan Tebangan Lembak di Bengalon" dengan kontraktor yang ditunjuk. Uji analisis data dibandingkan langsung dengan menyertakan biaya konstruksi bagian-bagian pendukung terkait integrasi jalan pengalih sebagai kolam kontrol debit. Bagian-bagian tersebut antara lain penambahan pagar, penambahan pipa darurat aliran air, dan penambahan kepadatan timbunan.

\section{HASIL DAN PEMBAHASAN}

Metode pengelolaan limbah cair pada titik penaatan (compliance point) dilakukan dengan menggunakan metode konfigurasi 2 kolam pengendap, yaitu kolam kontrol debit dan kolam pengendapan atau lazim disebut kolam labirin. Kuantitas air dapat dikontrol dengan adanya kolam kontrol debit. Tampungan hidup kolam kontrol Kemuning didesain mampu menampung sementara air hujan yang turun dengan total volume maksimum $845.000 \mathrm{~m}^{3}$ pada elevasi RL10. Dengan besarnya tampungan hidup pada kolam kontrol debit, kualitas limbah cair dari hasil pertambangan diharapkan dapat diolah dengan maksimum. Debit keluaran dihitung dengan menggunakan asumsi hujan kala ulang 100 tahun yang berlaku di KPC yaitu setara dengan hujan $123 \mathrm{~mm} /$ hari. Hujan kala ulang 100 tahun ini berarti hanya $1 \%$ probabilitas hujan sebesar $123 \mathrm{~mm} /$ hari terjadi dalam waktu 1 tahun. Angka ini diambil sebagai kondisi terburuk dan dipakai pula untuk menguji ketahanan bangunan terhadap curah hujan yang tinggi. Tabel dan gambar berikut menjelaskan besaran penundaan debit pada struktur pada berbagai kondisi perubahan rencana muka tambang hingga akhir tahun 2021.

Tabel 1. Routing debit banjir periode tahun 2018 - 2021

\begin{tabular}{ccrrr}
\hline $\begin{array}{c}\text { Sekuen } \\
\text { Tambang }\end{array}$ & $\begin{array}{c}\text { Debit masukan } \\
\left(\mathrm{m}^{3} / \mathrm{s}\right)\end{array}$ & $\begin{array}{c}\text { Debit keluaran } \\
\left(\mathrm{m}^{3} / \mathrm{s}\right)\end{array}$ & $\begin{array}{c}\text { Pengurangan debit } \\
\left(\mathrm{m}^{3} / \mathrm{s}\right)\end{array}$ & \% Pengurangan \\
\hline Akhir 2019 & 29.83 & 2.76 & 27.12 & 90.77 \\
Akhir 2020 & 30.92 & 2.91 & 28.00 & 90.56 \\
Akhir 2021 & 30.92 & 2.91 & 28.00 & 90.56 \\
\hline
\end{tabular}

Kualitas air dapat direkayasa dengan lebih mudah setelah kuantitas air dapat dikontrol. Dengan adanya debit yang relatif kecil (akibat adanya kontrol debit), beban kualitas air akan mengikuti nilai debit dan berbanding lurus. Semakin kecil debit yang dikontrol maka beban untuk perbaikan kualitas akan semakin turun. Berdasarkan Perda Kaltim 02-2011, parameter yang perlu di kontrol antara lain adalah $\mathrm{Fe}, \mathrm{Mn}, \mathrm{pH}$, dan TSS. Semua parameter yang disebutkan harus memenuhi batas ambang yang diperkenankan. Kualitas Fe, Mn, dan $\mathrm{pH}$ dapat diprediksi dengan data Core Drill Pit B/C. Di lain hal TSS yang terbentuk oleh erosi tanah yang terbentuk ketika hujan turun akan diprediksi dengan rumus USLE.

Dalam penambangan batu bara, Air Asam Tambang (AAT) terbentuk oleh material PAF yang mengandung campuran sulfur. Total Sulfur (TS) adalah parameter umum untuk memprediksi penurunan nilai pH (derajat keasaman). Ion Sulfur bereaksi dengan Mangan menjadi Mangan Sulfida $(\mathrm{MnS})$ dan ion Fe bereaksi dengan Pyrite membentuk $\mathrm{FeS}_{2}$. Bagaimanapun juga untuk mendapatkan analisa yang komprehensif, $\mathrm{pH}$ juga diprediksi dengan melihat data seam batubara dimana jika TS $>0,34 \%$ akan lebih condong membentuk AAT (Mery Marthen, Trubaindo, 2013). Data pada pit B/C menunjukan bahwa PAF lebih dominan sehingga keberadaan kontrol debit untuk memudahkan pengolahan kualitas praktis akan berperan penting dalam proses perbaikan kualitas air. Tabel 2 menunjukkan data kandungan sulfur pada penambangan pit B/C. 


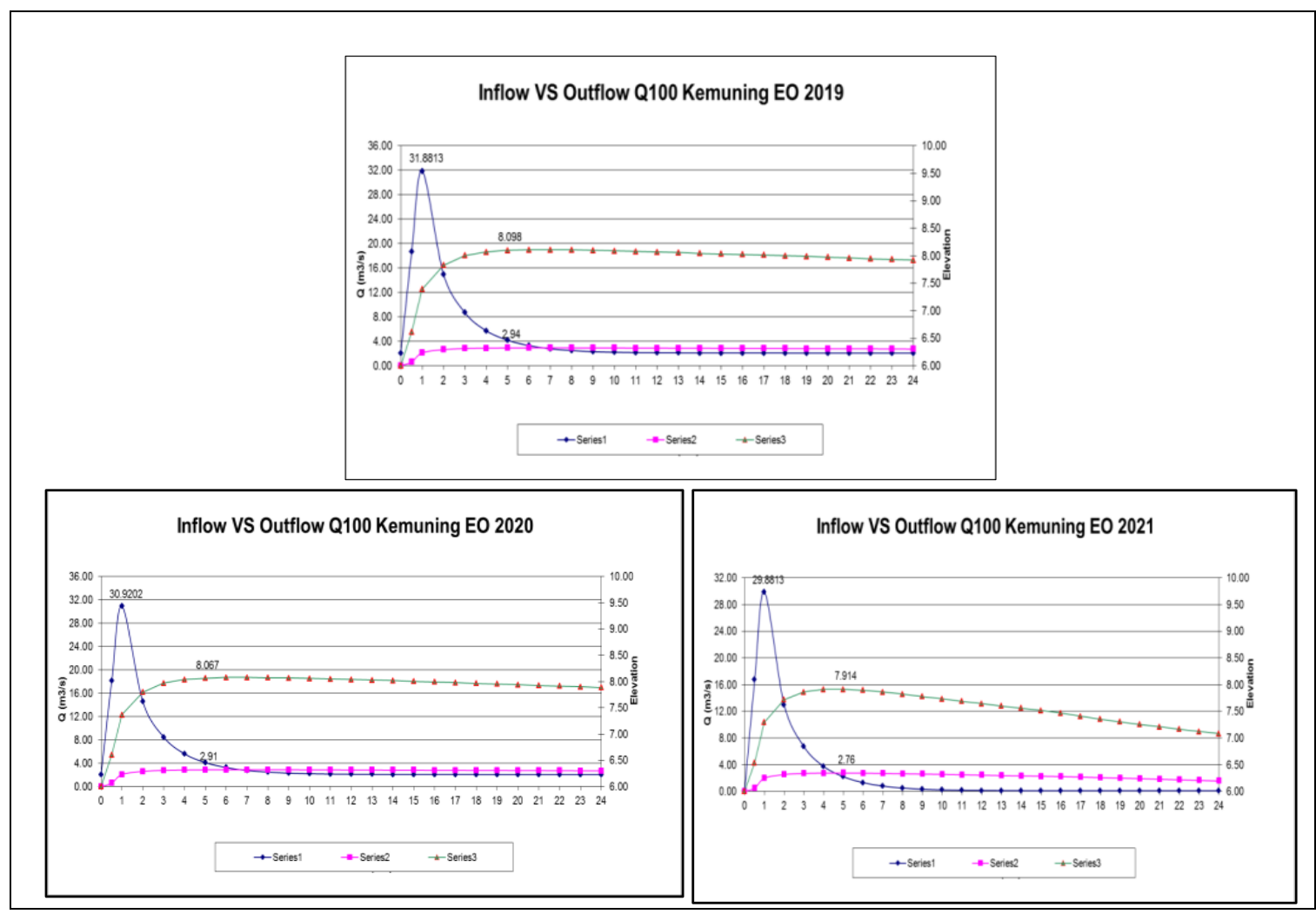

Gambar 2. Grafik penelusuran debit banjir pada bermacam perubahan muka tambang

Tabel 2. Kandungan sulfur pada seam pit B/C Bengalon

\begin{tabular}{lcc}
\hline Sekuen Tambang & TS rerata $(\%)$ & Tendensi PAF/NAF \\
\hline 2019 & 1.44 & PAF \\
2020 & 1.29 & PAF \\
2021 & 0.92 & PAF \\
2022 & 1.19 & PAF \\
\hline
\end{tabular}

Asistensi dan permohonan izin untuk melakukan pengalihan jalan kepada pihak pemerintah telah dilakukan. Presentasi teknis telah disampaikan kepada Dinas Lingkungan hidup, Dinas Pekerjaan Umum, hingga Dinas Tata Ruang. Mengemuka 2 alternatif pengalihan jalan tebangan lembak untuk dipilih. Secara detail kedua alternatif tersebut dijabarkan pada keterangan berikut.

Alternatif 1 - Membangun timbunan kolam dan badan jalan terpisah. Badan jalan akan dibangun diluar sistem kolam sehingga jarak jalan pengalihan menjadi lebih panjang. Jarak pembangunan jalan pengalih pada alternatif ini akan lebih dekat ke Sungai Bengalon. Kondisi topografi yang berada pada area relative datar membutuhkan analisis detail pada sisi geoteknik. Metode pelaksanaan timbunan juga tentunya akan lebih sukar dilakukan pada area rawa.

Alternatif 2 - Membangun timbunan kolam dan badan jalan sebagai satu kesatuan. Panjang jalan pengalih pada alternatif ini menjadi lebih pendek. Timbunan yang dibutuhkan untuk pembangunan jalan didesain lebih tinggi dari seharusnya. Hal ini memberikan efek tunda debit sehingga air bisa tertampung dalam reservoir sementara. Dalam hal ini fungsi kontrol terhadap debit air yang keluar dan dapat diolah menjadi lebih mudah. Tampak atas rencana dua alternatif diatas ditampilkan secara komprehensif pada gambar 3 berikut. 

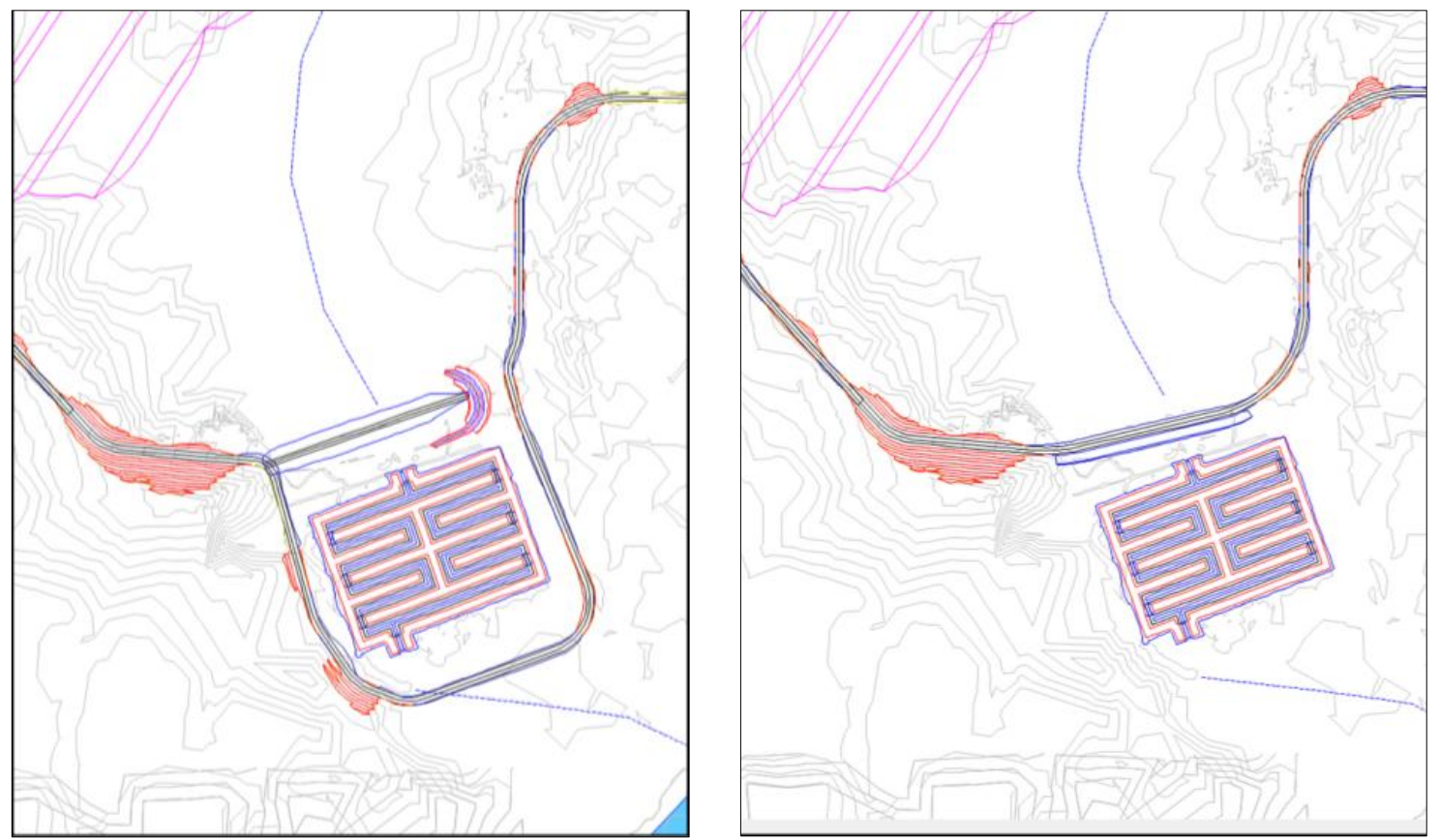

Gambar 3. Alternatif 1 jalan pengalih (kiri) dan alternatif 2 jalan pengalih (kanan)

Alternatif 2 memiliki beberapa keuntungan jika dilihat dari beberapa parameter yaitu panjang total jalan yang akan ditempuh masyarakat dan total biaya keseluruhan yang semakin berkurang.

Tabel 3. Perbandingan alternatif 1 dan alternatif 2

\begin{tabular}{lrr}
\hline Parameter & Alternatif $\mathbf{1}$ & \multicolumn{1}{c}{ Alternatif 2 } \\
\hline Panjang total ruas jalan & $6,22 \mathrm{~km}$ & $5,53 \mathrm{~km}$ \\
Elevasi jalan di area kolam Kemuning & RL7,5 & RL10 \\
Total area bukaan lahan & $3,07 \mathrm{ha}$ & $0,99 \mathrm{ha}$ \\
Total volume topsoil removal & $36.816 \mathrm{bcm}$ & $11.848 \mathrm{bcm}$ \\
Total volume fill material & $74.724 \mathrm{ccm}$ & $35.824 \mathrm{ccm}$ \\
Total volume beton & $55 \mathrm{~m}^{3}$ & $45 \mathrm{~m}^{3}$ \\
Total biaya pekerjaan & $258.403 * \mathrm{n}$ & $153.234^{*} \mathrm{n}$ \\
\hline *n faktor pengali biaya (tidak untuk dipublikasikan) & &
\end{tabular}

Berdasarkan deskripsi dan perbandingan pada tabel 1 total biaya konstruksi turun cukup signifikan pada alternatif 2. Sehingga alternatif 2 menguntungkan pada sisi bisnis perusahaan. Dalam operasionalnya, ruas jalan pengalih perlu dilengkapi dengan kelengkapan-kelengkapan lain mengingat kemungkinan terjadinya interaksi antara pengguna jalan dan pengguna kolam (KPC). Kelengkapan itu antara lain yaitu penambahan pagar dan pipa aliran darurat ketika hujan melebihi ambang batas rencana. Gambar 4 menunjukkan foto udara tampak atas hasil pembangunan integrasi pekerjaan jalan dan kolam labirin yang telah selesai dibangun. 


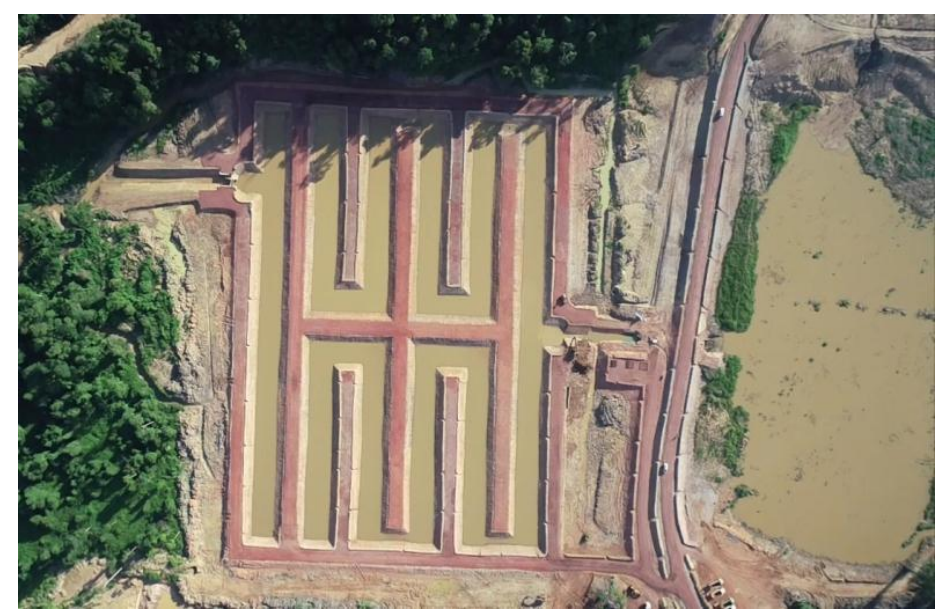

Gambar 4. Foto udara konstruksi jalan pengalih dan kolam labirin

\section{SIMPULAN DAN REKOMENDASI}

Berdasarkan analisis dalam pembahasan masalah dapat disimpulkan bahwa integrasi pembangunan jalan dan kolam kontrol debit Kemuning menguntungkan secara biaya keseluruhan proyek. Pengurangan biaya pembangunan infrastruktur mencapai angka $41 \%$. Tercatat bukaan lahan yang diperlukan juga akan lebih kecil karena hanya 1 ruas bukaan saja yang dipakai. Selain itu dengan berkurangnya jumlah material timbunan yang diperlukan, bukaan untuk timbunan tanah pucuk serta borrow area secara praktis juga berkurang. Secara fungsi, tidak ada penurunan fungsi kolam retensi akibat adanya integrasi kolam dengan jalan. Pengelolaan kualitas air baik dari sisi kuntitas dan kualitas tetap dapat dipertahankan.

Perencanaan infrastruktur jangka panjang untuk penambangan perlu dilihat dalam skala lebih luas. Adanya potensi integrasi jalan dan kolam perlu diidentifikasi lebih awal dan dituangkan dalam master plan perencanaan infrastruktur tambang. Potensi penghematan akan lebih bisa dimaksimalkan jika identifikasi dan analisis dapat dilakukan lebih mendalam pada tahapan awal perencanaan.

\section{DAFTAR PUSTAKA}

Bupati Kutai Timur. 2012. Surat Keputusan Bupati. Lembaran Kabupaten Kutai Timur No.620/K.628 Tahun 2012. Sangatta

Civil\&Environmental Planning Section. 2015. Guideline of Mine Water Management. Arsip Internal (tidak diterbitkan untuk umum). Mine Planning Department. Sangatta.

Civil\&Environmental Planning Section. 2018. Rencana Tata Kelola Air 2019-2022. Arsip Internal (tidak diterbitkan untuk umum). Mine Planning Department. Sangatta.

Gubernur Kalimantan Timur. 2012. Penyelenggaraan Jalan Umum Dan Jalan Khusus Untuk Kegiatan Pengangkutan Batubara Dan Kelapa Sawit. Lembaran Daerah Provinsi Kalimantan Timur Tahun 2012 Nomor 10. Samarinda.

Gubernur Kalimantan Timur. 2011. Peraturan Daerah Provinsi Kalimantan Timur Nomor 02 Tahun 2011 Tentang Pengelolaan Kualitas Air dan Pengendalian Pencemaran Air. Lembaran Daerah Provinsi Kalimantan Timur Tahun 2011 Nomor 02. Samarinda

Marthen, Mery. 2013. Identifikasi Potensi Pembentukan Air Asam Tambang, NAPP vs. NTAPP. PT Trubaindo Coal Mining. Bunyut.

PT Kaltim Prima Coal. 2018. Dokumen Kontrak No.KPC-89-0069. Arsip Internal (tidak diterbitkan untuk umum). Supply Chain Department. Sangatta. 
PROSIDING TPT XXVIII PERHAPI 2019 